\title{
Using and Analyzing of Distance Education Model for Adnan Menderes University 5(I) Courses*
}

\author{
Mahmut Sinecen, Fatma Sinecen \\ Adnan Menderes University, Aydin, Turkey
}

\author{
Osman Sinecen \\ Pamukkale University, Denizli, Turkey
}

\begin{abstract}
The different models have led to occurring on education because of transferring, using, accessing, and sharing of knowledge. Today, distance education model is the most important and effective use in these models. The lack of teaching staff and the limited field of education areas are the most important factor in the use of distance education model. Therefore, required courses (Ataturk's Principles and History of Turkish Language, Foreign Language) which are Law 5(I) of 2547 under Article have been transferred to the distance education system instead of formal education in the Adnan Menderes University. In this article, requirements, using reasons and analyzing of the results of this model are given.
\end{abstract}

Keywords: distance education, infrastructure, 5(I) courses

\section{Introduction}

In our country which has adopted the concept of life long education, many state institutions and organizations, especially universities, have added distance education model into their own with advancing technology and Internet infrastructure (Al \& Madran, 2004; Altiparmak, Kurt, \& Kapidere, 2011; Odabas, 2003; Duzakin \& Yalcinkaya, 2008). Distance education is an education model that uses every kind of electronic communication (Sinecen, 2011). With course being followed with distance education, even though there are disadvantages such as students and instructors' not being in the same environment, students's not socializing with each other, and not being able to make correction in case of students wrong knowledge acquisition, there are advantages such as students' being able to reach to the knowledge whenever they want and providing comprehensibleness with interactive contents such as voice-video, being able to listen the courses synchronized and unsynchronized, being able to keep course contents updated, not needing the physical conditions in educational institutions, and expert instructors' being able to give the lecture from their location (Ozarslan, 2008; Cetin, Cakiroglu, Bayilmıs, \& Ekiz, 2004; Adiyaman, 2002; Sen, Atasoy, Aydin, \& Nesrin, 2010; Ekiz, Bayam, \& Unal, 2003).

Adnan Menderes University (ADU), with its faculties located in eight different positions and 16 vocational

\footnotetext{
* Acknowledgments: This study is supported by Adnan Menderes University Scientific Research Projects coordinatorship within project with code of MF-14012.

Mahmut Sinecen, assistant professor, Ph.D., Engineering Faculty, Adnan Menderes University, Turkey.

Fatma Sinecen, lecturer, M.A., Kosk Vocational School, Adnan Menderes University, Aydin, Turkey.

Osman Sinecen, lecturer, bachelor degree, Education Faculty, Pamukkale University, Denizli, Turkey.
} 
schools and graduate schools, is one of the most distributed structured universities. At this point, assigning instructors and giving lectures is making it difficult in terms of cost, time, and place. In this regard, ADU, with decision taken in session dated 08/08/2014 and numbered 2014-12 has accepted to use distance education for the courses mentioned in article 5(I) of legislation numbered 2547.

In this article, in first chapter, introduction and literature which belongs to distance education system promotion is mentioned. In second chapter, information about hardware and software materials used for ADU distance education infrastructure is given. In chapter three, web site created for ADU distance education and user statistics for this web site are explained. In chapter four, the assessment and evaluation application developed for the distance education performed in ADU is mentioned. In chapter five, results and at last chapter, conclusion and suggestions are mentioned.

\section{Method}

Infrastructure of ADU distance education is created in two steps. The first step is preparation of contents and the second step is publication of contents prepared in first step. Different hardware and software products are used for both steps. In this chapter, the hardware and the software used for both steps are explained.

\section{Preparation of Contents}

The contents prepared for the courses that students need to take need to be organized for some specific standard. It is important just because the components of software and hardware that need to be used by instructors to provide this service are the most basic and the simplest affect ease of use. With the aim of preparing contest for distance education in ADU, the presentation template shown in Figure 1 is designed and instructors prepare their presentations with reference to this template.

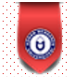

\section{Asıl başlık stili için tıklatın}

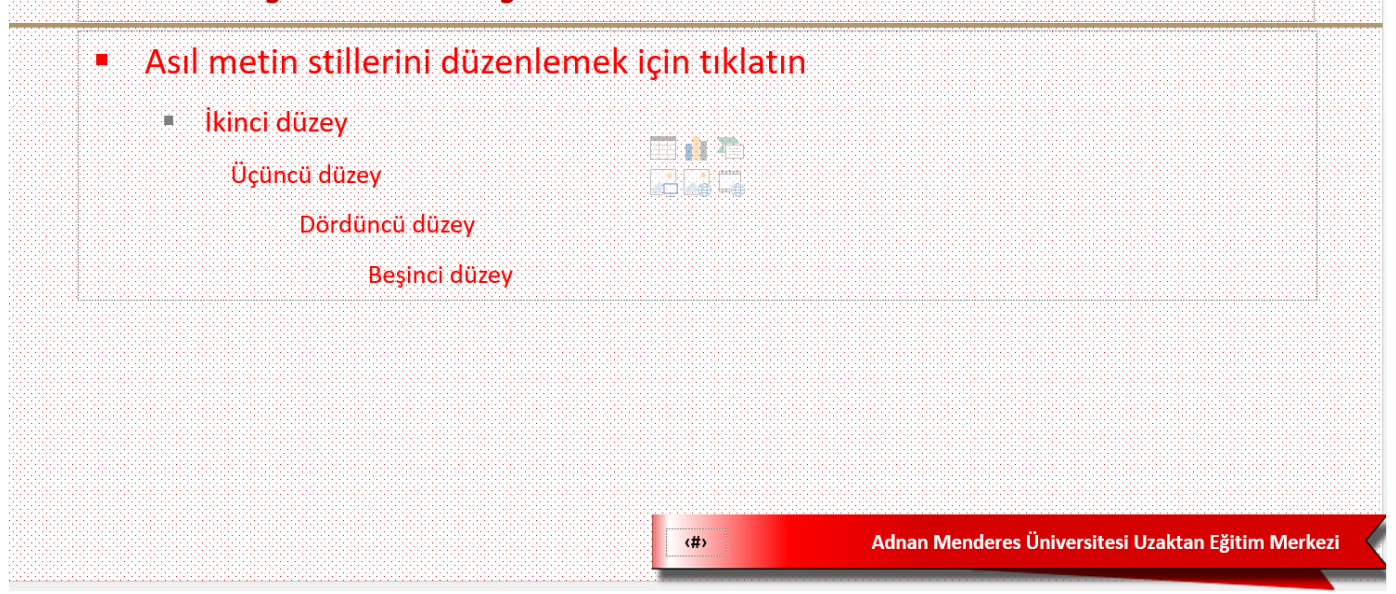

Figure 1. ADU distance education content preparing presentation template.

\section{Software}

The software Ispring which is an add-on to Powerpoint is used to prepare interactive presentations. Students, 
in the contents prepared by this software, take education connected with scenario that is prepared for the course from the beginning of the subject and until the ending of the subject. Besides, by Ispring software saving presentations as SCORM (Sharable Content Object Reference Model) packets, the copy-paste feature of the person who watches the presentation is disabled.

Just about to use in presentations prepared, a lot of different graphics, animations, pictures, or visual materials are created with Adoce Creative Cloud. By using cloud technology, the contents prepared in this software become available for the instructors who prepared the contents from any computer with Internet connection.

Sometimes, instructors need to use images of some specific parts of various visual or audial materials which are not able to be copied and various special education software from their own computers. In situations like this, by saving needed materials from screen images with Adobe Captivate and Camtasia programs, contents are developed.

To submit the prepared contents to the students, it is needed to create a web site which has a content management system. MOODLE software which is the most used and has the most advanced content management system worldwide about e-learning is used to serve ADU distance education contents. The most important feature of this software is to have an Open Source Code structure and to be able to develop specifically for the person or insitution by add-ons prepared by multiple developers.

One of the most important needs of distance education infrastructure is video conference system which is used for giving synchronized educations. Adobe Connect software is preferred in ADU Distance Education infrastructure as the most used video conference system. It is provided for instructors to use the live video conference system for their courses whenever they want by connecting MOODLE as add-on to the Distance Education content management system. Also, the courses given live are automatically saved and are added to web site. Thus, it is provided for ADU students to watch the courses they could not watch whenever they want as unsynchronized.

\section{Hardware}

For contents developing, instructors use computers with model of Hp Prodesk $600 \mathrm{G} 1$. To transfer different documents during the presentations in video conference system and to prepare contents, Avermedia Spb350 Hd Document Camera is used. By using document camera, instructors provide dynamic education system by transferring any needed visual object or document to the computer screen. In preperation of course videos, to transfer instructor's voice more clearly by filtering the outer voice, Sennheiser Sc 630 Hd headphone sets are used. When transferring the image of instructors in the course videos, to obtain a clear and HD transfer, Logitech C920 is used. For giving the course and for preparing visual material to increase the effect of cursor on the computer screen, Wacom Intuos PTH-851 Pro Large Graphic Pads are used to make it easier for instructors.

In addition to content developing software and hardware mentioned, it is needed to have storage space and server service to save contents and video visuals. In this regard, because of doing a setup planning as creating a virtualization system for ADU Distance Education infrastructure, physical server to be used is chosen with features given below. In this server, there are two different active servers as video conference and contents management system servers. 
(1) IBM 2*Xeon M4 8CE5-2650 Dual Core Xeon Processor

(2) 128 GB Ram

(3) 1.2 TB SAS Disk (3x300 GB+300 GB)

(4) Server (Video Conference)

Minimum requirements needed for the setup of Adobe Connect software and configuration information within ADU are shown in Table 1.

Table 1

Adobe Connect Video Conference Software System Configuration

\begin{tabular}{llll}
\hline & & Required & Existing \\
\hline \multirow{5}{*}{ Hardware } & Processor & 2 Ghz Quad-Core Intel Xeon or faster & 2 Ghz, 4 Core Intel Xeon \\
& RAM & 16 GB RAM or bigger & 32 GB RAM \\
& HDD & 4 GB HDD (for setup ofAdobe Connect Enterprise), 150 & 500 GB HDD \\
& File system & GB HDD and enlarged video storage space & NTFS file system \\
\hline \multirow{5}{*}{ Software } & OptFS file system & Microsoft Windows Server 2008 R2 (64 Bit), 2012 R2 (64 Microsoft Windows Server 2008 \\
& Virtualization & Vit) & R2 (64 Bit) \\
& Database & Microsoft SQL Server 2008 R3, 2008 R2, 2012 (64 Bit) & Microsoft SQL Server 2008 R3 \\
\hline Network & Ethernet & 100 Mbps (1 Gbps recommended) & 1 Gbps \\
\hline \multirow{5}{*}{ Ports } & RTMP & 1935 & 1935 \\
& HTTP & 80 or another HTTP port & 80 or another HTTP port \\
& SSL (If active) & 443 & None \\
& SMTP & 25 & 25 \\
& External database & 1433 & 1433 \\
\hline
\end{tabular}

\section{Server (Content Management System)}

System configuration needed for Moodle content management system and existing for ADU distance education is shown in Table 2.

Table 2

System Configuration for Moodle Contents Management

\begin{tabular}{llll}
\hline & Required & Existing \\
\hline \multirow{5}{*}{ Hardware } & Processor & Pentium IV 3.0 Ghz (dual core recommended) & 2 Ghz, 2 Core Intel Xeon \\
& RAM & 1 GB RAM (For each simultaneous 10 or 20 users) & 8 GB RAM \\
& HDD & $\begin{array}{l}\text { 160 MB HDD (for Moodle setup), 5 GB HDD and } \\
\text { enlarged video storage space }\end{array}$ & 200 GB HDD \\
\hline \multirow{6}{*}{ Software } & Operating system & Windows XP/2000/2003, Solaris 10, Mac OSX, Netware & Ubuntu 12.04 LTS \\
& Web server & IIS (Winux & Apache \\
& Database & MYSQL 5.1.33, PostgreSQL 8.3, MSSQL 9.0, Oracle & MYSQL \\
& Scripting language & 10.2, SQLite 2.0 & PHP minimum 5.3.2 \\
\hline
\end{tabular}

One of the most important requirement for students and instructors is servers used for distance education to be actively working 7/24. By using Veeam Backup software, it is provided to take backups periodically just to prevent system from collapsing and going back to older version. 
Another issue that can occur in distance education is controlling the bandwidth efficiency in access of video or contents. By using NetFlow Traffic Analyzer software, with this issue being under control constantly, it is enabled for web supervisors to do necessary intervention.

For transferring the courses uninterruptedly in case of any electricity interruption, uninterrupted power sources should be used. In this regard, EMERSON Rack type Uninterrupted Power Source (5 KVA) is used to keep system working and actively being used.

\section{Content Sharing (ADUZEM Web Site)}

At Adnan Menderes University 5(I) courses distance education infrastructure work, http://aduzem.adu.edu.tr web site that is shown in Figure 2 was created for courses and contents of Turkish Language, Ataturk's Principles and History of Turkish Revolution and Foreign Language courses were transferred to this web site. The courses given as live and their recorded videos are hosted in the http://aduzemconnect.adu.edu.tr web site. The problem encountered by users about different interfaces is attempted to prevent with inter-sessional connections between these two web sites.

The visitor information, such as instant, demographic, geographic, gender, etc., is taken with the ADUZEM web site Google Analytics connection. In the light of statistical information obtained by this approach, updating the web site is planned. According to the gender information of web site visitors that is shown in Figure 3, it is observed that an approximately equal rate of women and men examines the web site. This approximately equal rate emphasizes that the web site has same significance for each individual type about course tracking.

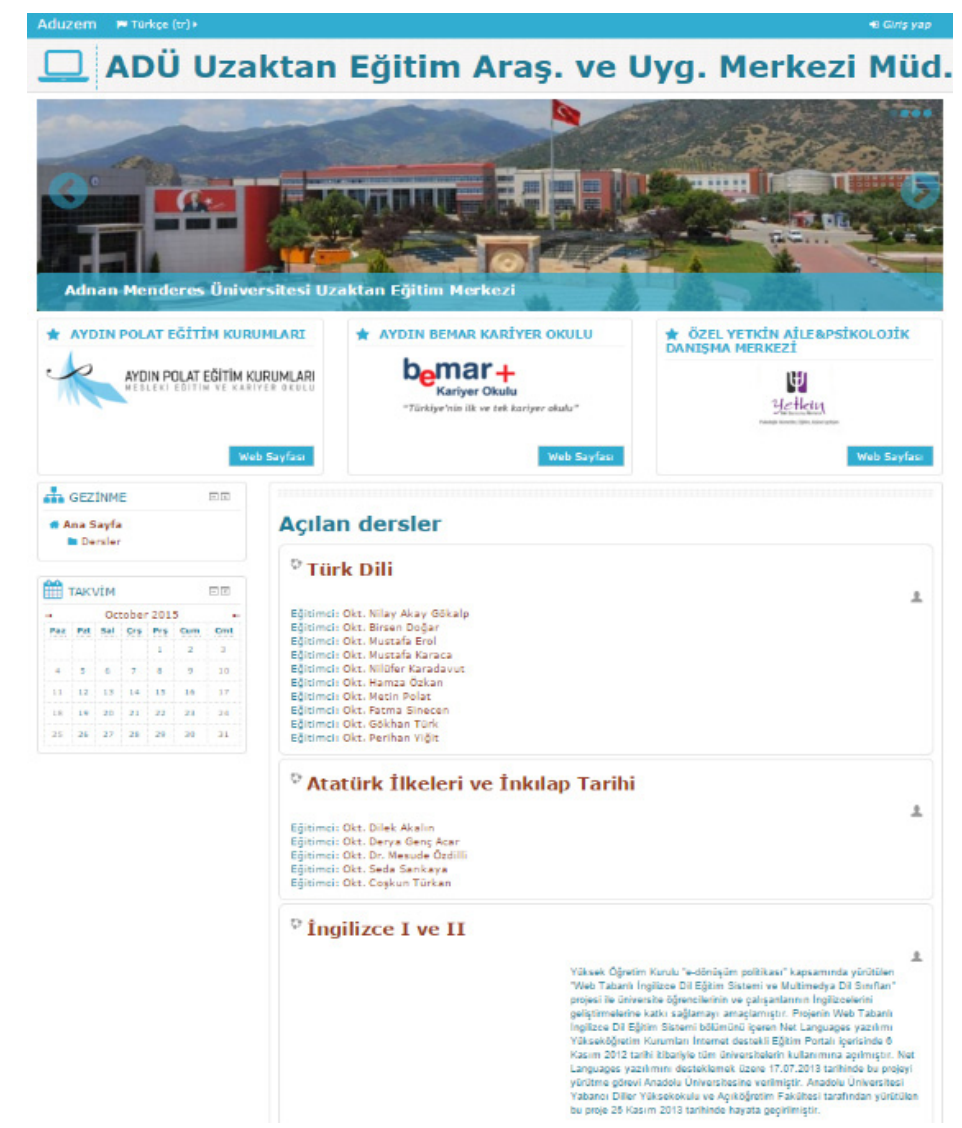

Figure 2. ADUZEM web site. 


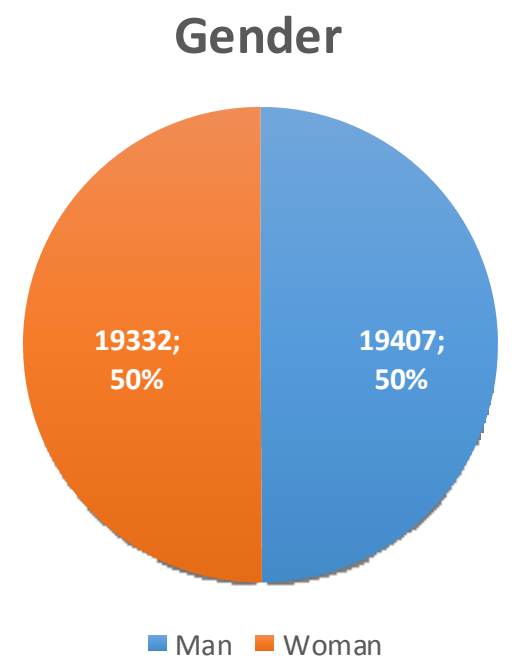

Figure 3. Rates of ADUZEM visitors according to gender.

As shown in Figure 4, age range of 18-24 has higher number of web site visitors than the other age ranges. When it is considered that courses are concerned with the university students, it is expected that 18-24 age group has higher number of visitors. Total number of people in 45 and older age group is 1,349. As a consequence of that, it reveals the thought that this group has a special interest about these courses or people in the foreign countries are aroused curiosity to the Turkish language and history.

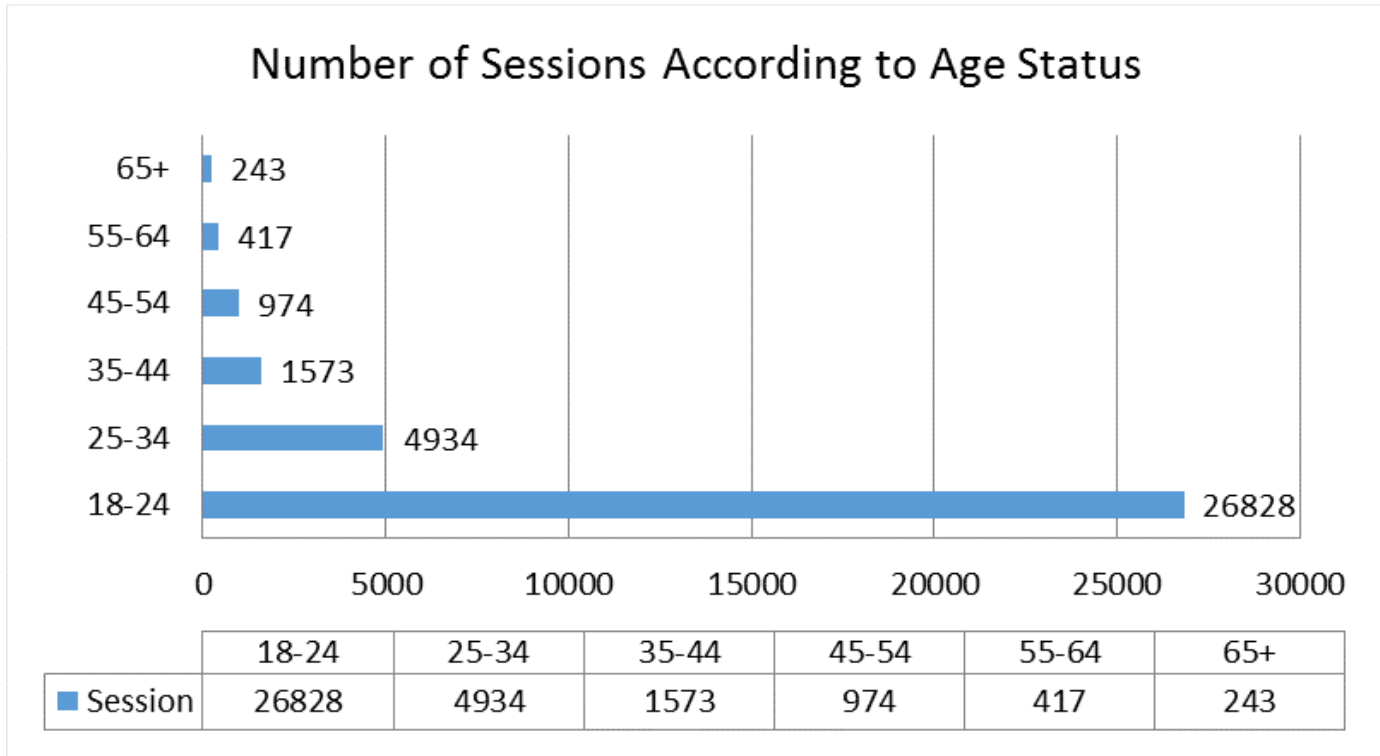

Figure 4. The number of sessions of ADUZEM web site according to age status.

In the light of the map that is shown in Figure 5, color change occurs from the darkest blue color towards gray color. The darkest blue color represents the biggest visitor population, light blue color represents the area that has less visitor population, and grey color represents the area that has no visitor. The highest number of users is from Russia after Turkey as it can be seen from Table 3. At the same table, login information of new visitors 
and their waiting times in the sub-pages of the web site are also specified. Accordingly, the highest average session duration is from Germany after Turkey.

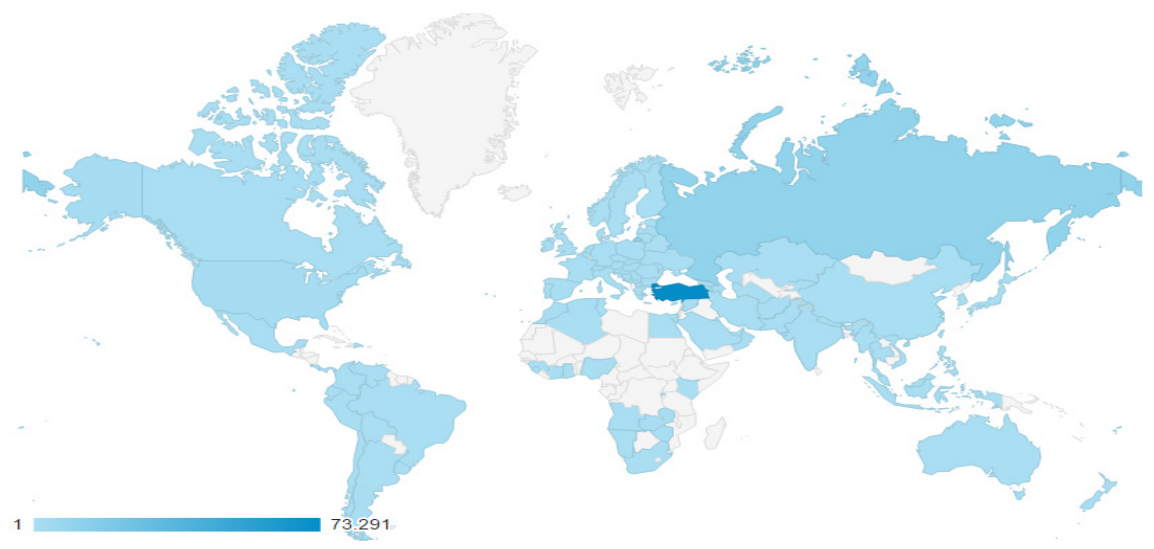

Figure 5. Worldwide visitor demography of ADUZEM web site.

Table 3

Worldwide Login Rates of ADUZEM Web Site

\begin{tabular}{lllllll}
\hline Region & Session & $\begin{array}{l}\text { New session } \\
\text { frequency }\end{array}$ & New users & Bounce rate & Page/Session & $\begin{array}{l}\text { Avg. session } \\
\text { duration }\end{array}$ \\
\hline Turkey & 73291 & $69,62 \%$ & 51026 & $63,78 \%$ & 2,59 & 89,28 \\
Russia & 10040 & $98,11 \%$ & 9850 & $99,60 \%$ & 1,01 & 1,21 \\
United States & 1960 & $95,31 \%$ & 1868 & $81,53 \%$ & 1,24 & 44,10 \\
China & 239 & $97,91 \%$ & 234 & $89,96 \%$ & 1,07 & 24,77 \\
Germany & 185 & $88,11 \%$ & 163 & $75,14 \%$ & 1,83 & 57,62 \\
India & 151 & $76,82 \%$ & 116 & $74,17 \%$ & 1,60 & 56,23 \\
United Kingdom & 138 & $90,58 \%$ & 125 & $74,64 \%$ & 1,47 & 23,89 \\
Japan & 136 & $99,26 \%$ & 135 & $92,65 \%$ & 1,00 & 12,96 \\
Netherlands & 101 & $88,12 \%$ & 89 & $86,14 \%$ & 1,28 & 25,11 \\
TOTAL & 88347 & $74,23 \%$ & 65581 & $68,96 \%$ & 2,34 & 76,42 \\
\hline
\end{tabular}

The highest number of users who log in to the web site across Turkey is from Izmir province after Aydin province (Figure 6). In spite of this, Antalya is the province which is the highest average session duration as it is seen in Table 4.

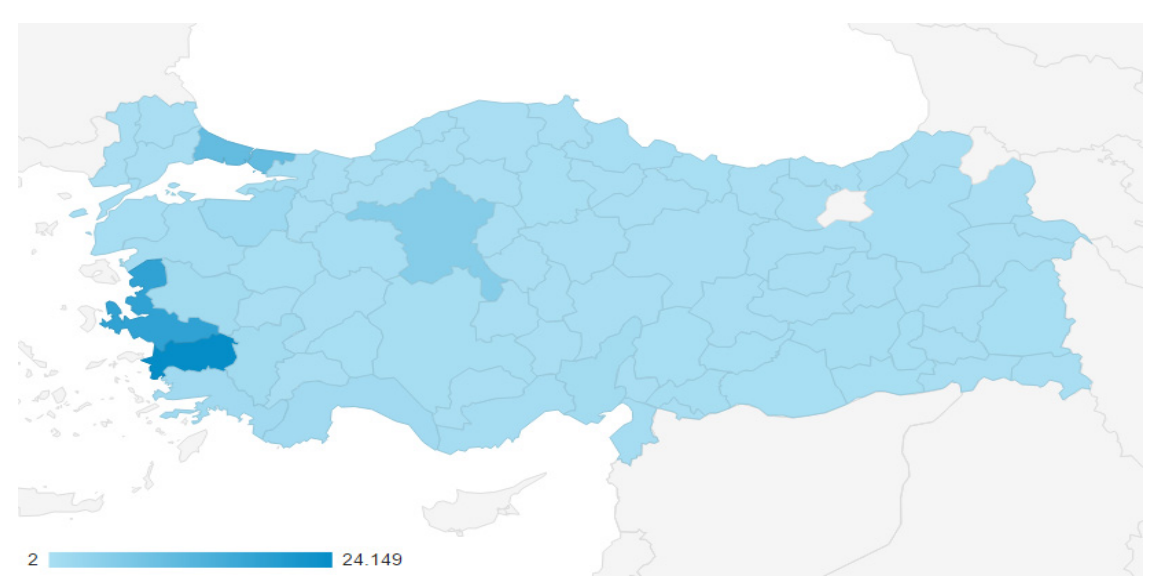

Figure 6. Visitor demography of ADUZEM web site across Turkey. 
Table 4

Login Rates of ADUZEM Web Site Across Turkey

\begin{tabular}{lllllll}
\hline Region & Session & $\begin{array}{l}\text { New session } \\
\text { frequency }\end{array}$ & New users & Bounce rate & Page/Session & $\begin{array}{l}\text { Avg. session } \\
\text { duration }\end{array}$ \\
\hline Aydin & 24149 & $66,36 \%$ & 16026 & $58,94 \%$ & 2,98 & 103,46 \\
Izmir & 17835 & $68,15 \%$ & 12155 & $64,85 \%$ & 2,42 & 81,59 \\
Istanbul & 10214 & $70,65 \%$ & 7216 & $67,18 \%$ & 2,40 & 77,24 \\
Ankara & 5353 & $69,33 \%$ & 3711 & $64,51 \%$ & 2,51 & 91,44 \\
Bursa & 1854 & $71,47 \%$ & 1325 & $63,21 \%$ & 2,61 & 89,41 \\
Antalya & 1365 & $71,87 \%$ & 981 & $65,27 \%$ & 2,39 & 109,80 \\
Mugla & 1203 & $73,90 \%$ & 889 & $66,58 \%$ & 2,32 & 74,69 \\
Manisa & 1088 & $77,30 \%$ & 841 & $68,20 \%$ & 2,22 & 73,57 \\
Denizli & 1078 & $75,79 \%$ & 817 & $68,37 \%$ & 2,29 & 75,96 \\
Adana & 980 & $75,51 \%$ & 740 & $70,82 \%$ & 2,14 & 69,19 \\
TOTAL & 73291 & $69,62 \%$ & 51026 & $63,78 \%$ & 2,59 & 89,28 \\
\hline
\end{tabular}

\section{Assessment and Evaluation}

In compliance with numbered 1 senate decision "5(I) Courses Executive Essentials" that is received in session dated 08/08/2014 and numbered 2014-12 within the scope of Adnan Menderes University 5(I) courses, it is stated that the Turkish Philology, Ataturk's Principles, and History of Turkish Revolution and Foreign Language courses will be performed as distance education and for this purpose, preparing the necessary infrastructure is provided. Within this scope, the establishment of 5(I) Courses Coordinatorship that will be responsible of Chairmanship of Departments and instructors related these courses and that will fulfill the test coordination, creation of infrastructure that will provide taking course notes, visual or audial materials online without any compulsory attendance by students are described in accordance with these principles in detail.

Courses that students passed successfully will be seen as "E" (Exempt) in their transcript in accordance with the results of exemption exams which will be held at the beginning of the fall semester of each academic year and with results of exams in the scope of 5(I). Students who pass the course in the final or resit exams will have "P" (Passed) statement in their transcript and students who fail at course will have "F" (Fail) statement in their transcripts. All students attend these exams across the university and success rates of exams are analyzed depending on units of the university (Table 5). In addition, students, by assessing courses, can report their opinions and suggestions about courses via student information system which they use to see exam results.

Table 5

The Number of 5(I) Exam Results of ADU Units in 2014/2015 Academic Year

\begin{tabular}{|c|c|c|c|c|c|c|c|c|c|c|c|c|c|c|c|c|c|c|}
\hline \multirow{2}{*}{ NAME OF UNIT } & \multicolumn{3}{|c|}{ AI101 } & \multicolumn{3}{|c|}{ AI102 } & \multicolumn{3}{|c|}{ TD101 } & \multicolumn{3}{|c|}{ TD102 } & \multicolumn{3}{|c|}{ YD101 } & \multicolumn{3}{|c|}{ YD102 } \\
\hline & P & $\mathrm{F}$ & E & $\mathrm{P}$ & $\mathrm{F}$ & E & $\mathrm{P}$ & $\mathrm{F}$ & E & $P$ & $\mathrm{~F}$ & E & $\mathrm{P}$ & $\mathrm{F}$ & E & $\mathrm{P}$ & $\mathrm{F}$ & E \\
\hline Atça VC & 259 & 81 & 136 & 353 & 123 & 130 & 280 & 85 & 133 & 236 & 70 & 129 & 256 & 19 & 125 & 132 & 137 & 123 \\
\hline $\begin{array}{l}\text { Aydın Fac. of } \\
\text { Economics }\end{array}$ & 85 & 14 & 110 & 147 & 27 & 97 & 85 & 6 & 106 & 90 & 5 & 106 & 114 & 3 & 113 & 57 & 40 & 106 \\
\hline Aydın VC & 576 & 320 & 299 & 758 & 553 & 278 & 546 & 427 & 308 & 508 & 345 & 283 & 535 & 88 & 258 & 431 & 458 & 303 \\
\hline $\begin{array}{l}\text { Aydin Voc. School of } \\
\text { Health }\end{array}$ & 156 & 30 & 125 & 208 & 106 & 119 & 150 & 36 & 128 & 148 & 31 & 126 & 153 & 10 & 123 & 122 & 78 & 133 \\
\hline $\begin{array}{l}\text { Aydın School of } \\
\text { Health }\end{array}$ & 166 & 45 & 234 & 230 & 111 & 250 & 145 & 46 & 233 & 143 & 63 & 230 & 185 & 44 & 243 & 137 & 162 & 241 \\
\hline
\end{tabular}


(table 5 continued)

\begin{tabular}{|c|c|c|c|c|c|c|c|c|c|c|c|c|c|c|c|c|c|c|}
\hline \multirow{2}{*}{ NAME OF UNIT } & \multicolumn{3}{|c|}{ AI101 } & \multicolumn{3}{|c|}{ AI102 } & \multicolumn{3}{|c|}{$\overline{T D 101}$} & \multicolumn{3}{|c|}{ TD102 } & \multicolumn{3}{|c|}{ YD101 } & \multicolumn{3}{|c|}{ YD102 } \\
\hline & $\mathrm{P}$ & $\mathrm{F}$ & E & $P$ & $\mathrm{~F}$ & E & $\mathrm{P}$ & $\mathrm{F}$ & $\mathrm{E}$ & $P$ & $\mathrm{~F}$ & E & $\mathrm{P}$ & $\mathrm{F}$ & E & $\mathrm{P}$ & $\mathrm{F}$ & E \\
\hline $\begin{array}{l}\text { School of Phy. Edu. } \\
\text { and Sports }\end{array}$ & 347 & 85 & 47 & 338 & 130 & 37 & 203 & 93 & 25 & 186 & 85 & 22 & 187 & 21 & 34 & 119 & 68 & 34 \\
\hline Bozdoğan VC & 131 & 23 & 67 & 210 & 50 & 61 & 131 & 33 & 64 & 139 & 30 & 62 & 147 & 9 & 66 & 97 & 83 & 64 \\
\hline Çine VC & 90 & 45 & 89 & 150 & 43 & 84 & 94 & 57 & 96 & 91 & 35 & 77 & 78 & 17 & 64 & 63 & 40 & 65 \\
\hline Davutlar VC & 4 & 60 & 1 & 5 & 2 & 1 & 3 & - & - & 3 & 1 & 3 & 3 & - & 4 & - & - & 4 \\
\hline State Conservatory & - & - & 1 & - & - & 1 & - & - & - & - & - & - & 1 & - & - & - & - & - \\
\hline Didim VC & 145 & - & 120 & 189 & 104 & 95 & 148 & 89 & 126 & 133 & 55 & 99 & 42 & 22 & 2 & 41 & 29 & 5 \\
\hline Faculty of Dentistry & - & - & 22 & - & - & 22 & - & - & 22 & - & - & 22 & - & - & 22 & - & - & 22 \\
\hline Faculty of Education & 321 & 37 & 230 & 377 & 128 & 241 & - & - & - & - & - & - & - & - & - & - & - & - \\
\hline Fac. of Arts and Sci. & 330 & 49 & 247 & 430 & 146 & 217 & 269 & 52 & 223 & 245 & 67 & 217 & 286 & 18 & 176 & 206 & 222 & 190 \\
\hline Fac. of Com. & 2 & - & 42 & 5 & 3 & 37 & 2 & - & 42 & 2 & 1 & 42 & 5 & 1 & 36 & 4 & 2 & 36 \\
\hline Kar. Mm. İnci VC & 264 & 86 & 155 & 340 & 186 & 147 & 230 & 133 & 152 & 214 & 94 & 129 & 264 & 46 & 155 & 152 & 176 & 155 \\
\hline Koçarlı VC & 55 & 26 & 29 & 68 & 49 & 20 & 57 & 31 & 25 & 42 & 32 & 28 & 53 & 8 & 28 & 36 & 34 & 26 \\
\hline Köşk VC & 108 & 35 & 114 & 158 & 62 & 105 & 102 & 45 & 116 & 94 & 35 & 121 & 112 & 19 & 117 & 64 & 80 & 117 \\
\hline Kuyucak VC & 146 & 46 & 59 & 221 & 100 & 47 & 127 & 72 & 64 & 130 & 41 & 59 & 158 & 15 & 56 & 91 & 88 & 51 \\
\hline Fac. of Engineering & 68 & 19 & 129 & 64 & 18 & 126 & 55 & 22 & 129 & 50 & 5 & 126 & 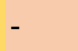 & 9 & 14 & - & 1 & 14 \\
\hline $\begin{array}{l}\text { Nazilli Fac. of Eco. } \\
\text { and Adm. Sci. }\end{array}$ & 710 & 126 & 897 & 1002 & 241 & 826 & 689 & 97 & 879 & 664 & 128 & 891 & 855 & 64 & 870 & 611 & 473 & 881 \\
\hline Nazilli VC & 488 & 214 & 295 & 674 & 414 & 250 & 487 & 309 & 277 & 419 & 214 & 272 & 444 & 74 & 264 & 653 & 548 & 396 \\
\hline $\begin{array}{l}\text { Naz. Voc. School of } \\
\text { Health }\end{array}$ & 64 & 6 & 99 & 136 & 5 & 97 & 72 & 16 & 93 & 69 & 17 & 99 & 64 & 4 & 95 & 68 & 45 & 101 \\
\hline Söke Fac. of Business & 45 & 6 & 141 & 52 & 25 & 122 & 44 & 6 & 140 & 43 & 12 & 143 & 101 & 4 & 8 & 53 & 62 & 8 \\
\hline Söke VC & 487 & 198 & 197 & 602 & 385 & 176 & 465 & 313 & 222 & 394 & 282 & 189 & 418 & 61 & 192 & 253 & 283 & 183 \\
\hline $\begin{array}{l}\text { Söke Voc. School of } \\
\text { Health }\end{array}$ & 64 & 15 & 56 & 98 & 30 & 52 & 51 & 20 & 54 & 61 & 20 & 52 & 59 & 7 & 51 & 37 & 40 & 52 \\
\hline Söke School of Health & 127 & 6 & 174 & 229 & 23 & 152 & 126 & 7 & 168 & 126 & 8 & 170 & 121 & 1 & 168 & 102 & 63 & 167 \\
\hline Sultanhisar VC & 228 & 92 & 167 & 348 & 129 & 125 & 209 & 118 & 175 & 188 & 78 & 157 & 195 & 25 & 142 & 143 & 104 & 143 \\
\hline Faculty of Medicine & - & 3 & 151 & 3 & 2 & 157 & 2 & - & 153 & 1 & 2 & 159 & - & 1 & 159 & - & 1 & 159 \\
\hline Faculty of Tourism & 119 & 13 & 198 & 147 & 78 & 160 & 115 & 22 & 195 & 113 & 61 & 187 & 19 & 2 & 3 & 19 & 21 & 3 \\
\hline $\begin{array}{l}\text { Tou. and Hotel Man. } \\
\text { Col. }\end{array}$ & 53 & 24 & 42 & 136 & 70 & 67 & 50 & 25 & 36 & 16 & 14 & 9 & 15 & 3 & 9 & 14 & 6 & 9 \\
\hline Fac. of Veterinary & 10 & 3 & 65 & 21 & 8 & 64 & 8 & 5 & 66 & 9 & 5 & 67 & 9 & 1 & 67 & 5 & 5 & 67 \\
\hline Yenipazar VC & 386 & 106 & 200 & 613 & 211 & 165 & 369 & 152 & 181 & 338 & 118 & 190 & 399 & 36 & 169 & 210 & 216 & 175 \\
\hline Fac. of Agriculture & 118 & 22 & 164 & 223 & 69 & 136 & 113 & 34 & 150 & 103 & 26 & 148 & 135 & 11 & 146 & 118 & 94 & 154 \\
\hline TOTAL & 6152 & 1835 & 5102 & 8535 & 3631 & 4664 & 5427 & 2351 & 4781 & 4998 & 1980 & 4614 & 5413 & 643 & 3979 & 4038 & 3659 & 4187 \\
\hline $\begin{array}{l}\text { AI101: Atatürk's Princ } \\
\text { AI102: Atatürk's Princ } \\
\text { TD101: Turkish Philol } \\
\text { TD102: Turkish Philol }\end{array}$ & $\begin{array}{l}\text { ciples a } \\
\text { ciples a } \\
\text { logy I } \\
\text { logy II }\end{array}$ & $\begin{array}{l}\text { and } \mathrm{Hi} \\
\text { and } \mathrm{Hi}\end{array}$ & istory & $\begin{array}{l}\text { of Tur } \\
\text { of Tur }\end{array}$ & $\begin{array}{l}\text { rkish R } \\
\text { rkish R }\end{array}$ & Revolu & ution I & & & $\begin{array}{l}\text { YD10 } \\
\text { YD10 }\end{array}$ & $\begin{array}{l}01: \mathrm{F} \\
02: \mathrm{F}\end{array}$ & $\begin{array}{l}\text { reign I } \\
\text { reign I }\end{array}$ & $\begin{array}{l}\text { Lan } \\
\text { Lan }\end{array}$ & $\begin{array}{l}\text { lage I } \\
\text { lage II }\end{array}$ & & F: Fai & ed & \\
\hline
\end{tabular}

Optical form that is used in exams is prepared by $5(\mathrm{I})$ courses coordinatorship and is printed by the printing house. Eighty grams of A4 paper is used for optical forms instead of special exam paper. The questions which should be answered by the students in exams are augmented after instructors who are tasked by Departments of Turkish Philology, Ataturk's Principles, and History of Turkish Revolution and School of Foreign Language prepares the questions. Optical forms are scanned by the scanner-enabled photocopier instead of optical readers, are analyzed by the software that is developed by $5(\mathrm{I})$ coordinatorship, and are transferred automatically to 
student information system and the interfaces that enable students to examine their exam paper online (http://sonuc.adu.edu.tr). Thus, the objections of the students are prevented in advance.

\section{Results}

Passing/Failure information depending on exam results of the students is obtained by Student Information System (OBIS) which is prepared by ADU Information Technology Department Software Branch Office. The total number of students registered was determined as 12,309 by year 2014 (Table 6). There is an expected difference between the number of registered students and number of students who attend to exams of 5(I) courses because of the various reasons such as lateral transfer, external transfer, and second university. In addition, the number of students differs from the attendance of students who register to courses in the previous year and take exams in new academic year.

Table 6

The Number of Registered Students According to Daytime and Evening Education in 2014/2015 Academic Year

\begin{tabular}{llllllll}
\hline \multicolumn{9}{c}{ Daytime Education } & \multicolumn{5}{c}{ Evening Education } \\
\hline Year & Man & Woman & Total & Man & Woman & Total & Final Total \\
\hline 2014 & 3946 & 4469 & 8415 & 2156 & 1738 & 3894 & 12309 \\
\hline
\end{tabular}

According to 5(I) courses execution principles, students of Adnan Menderes University have a right that enables to take an exam of required or all 5(I) courses at the same time. In this regard, the number of students that take an exam according to type of university units in 2014/2015 academic year is shown in Table 7. Percental equivalent of passing rates obtained by using Equation 1 according to units of the university and types of courses is shown in Table 8. Acceptance of students of Vocational College into the university with open admission and lack of interest of students seems to be an important factor in this low success rate. In addition, Table 8 provides information that students have low level passing rate at YD102 coded course that is one of the foreign language courses.

Table 7

The Total Number of Students Who Take the Exam According to 5(I) Courses in 2014/2015 Academic Year

\begin{tabular}{lllllll}
\hline & AI101 & AI102 & TD101 & TD102 & YD101 & YD102 \\
\hline VOCATIONAL COLLEGE & 7242 & 9635 & 7671 & 6780 & 5751 & 7128 \\
COLLEGE & 1350 & 1773 & 1157 & 1072 & 1031 & 1122 \\
FACULTY & 4496 & 5421 & 3731 & 3740 & 3252 & 3634 \\
TOTAL & 13088 & 16829 & 12559 & 11592 & 10034 & 11884 \\
\hline
\end{tabular}

\% Passtng Rate $=\frac{\text { Passtng }(\text { Ftnal or Restt })+\text { Exempt }(\text { Exemptton Exam })}{\text { The Total Number of Stud ents who Take the Course }}$ Equation 1

VC (AI101 Course $\%$ Passtng Rate $)=100 * \frac{3651+2208}{3651+1383+2208}=80,90$ 
Table 8

Percental Passing Rates of All Students Who Take the Exam According to 5(I) Courses in 2014/2015 Academic Year

\begin{tabular}{lllllll}
\hline & AI101 (\%) & AI102 (\%) & TD101 (\%) & TD102 (\%) & YD101 (\%) & YD102 (\%) \\
\hline VOCATIONAL COLLEGE & 80,90 & 73,51 & 74,76 & 77,91 & 92,00 & 65,78 \\
COLLEGE & 88,15 & 81,16 & 85,22 & 84,14 & 93,31 & 73,35 \\
FACULTY & 93,51 & 86,26 & 93,46 & 91,66 & 96,49 & 74,66 \\
\hline
\end{tabular}

According to exams for each course, Passing/ Failure/ Exempt status are shown in Table 9 based on type of units. It is seen that the highest passing rate is for YD101 course with $94 \%$ according to percental equivalent of passing rates which are determined between each other based on types of course and unit. Calculation of this rate is done according to Equation 2.

Table 9

The Number and Percental Rates of 5(I) Courses Passing/Failure Rate of Vocational College Students in 2014/2015 Academic Year

\begin{tabular}{|c|c|c|c|c|c|c|c|c|c|c|c|c|c|c|c|c|c|c|}
\hline \multirow{2}{*}{$\begin{array}{l}\text { COURSE } \\
\text { CODE } \\
\text { TYPE OF } \\
\text { UNIT }\end{array}$} & \multicolumn{3}{|c|}{ AI101 } & \multicolumn{3}{|c|}{ AI102 } & \multicolumn{3}{|c|}{ TD101 } & \multicolumn{3}{|c|}{ TD102 } & \multicolumn{3}{|c|}{ YD101 } & \multicolumn{3}{|c|}{ YD102 } \\
\hline & $\mathrm{P}$ & $\mathrm{F}$ & $\mathrm{E}$ & $\mathrm{P}$ & $\mathrm{F}$ & E & $\mathrm{P}$ & $\mathrm{F}$ & $\mathrm{E}$ & $\mathrm{P}$ & $\mathrm{F}$ & $\mathrm{E}$ & $\mathrm{P}$ & $\mathrm{F}$ & E & $\mathrm{P}$ & $\mathrm{F}$ & $\mathrm{E}$ \\
\hline $\mathrm{VC}$ & 3651 & 1383 & 2208 & 5131 & 2552 & 1952 & 3521 & 1936 & 2214 & 3207 & 1498 & 2075 & 3380 & 460 & 1911 & 2593 & 2439 & 2096 \\
\hline $\mathrm{C}$ & 693 & 160 & 497 & 933 & 334 & 506 & 524 & 171 & 462 & 471 & 170 & 431 & 508 & 69 & 454 & 372 & 299 & 451 \\
\hline FAC & 1808 & 292 & 2396 & 2471 & 745 & 2205 & 1382 & 244 & 2105 & 1320 & 312 & 2108 & 1524 & 114 & 1614 & 1073 & 921 & 1640 \\
\hline \multirow[t]{2}{*}{ TOTAL } & 6152 & 1835 & 5101 & 8535 & 3631 & 4663 & 5427 & 2351 & 4781 & 4998 & 1980 & 4614 & 5412 & 643 & 3979 & 4038 & 3659 & 4187 \\
\hline & $\mathrm{P}(\%)$ & $\mathrm{F}(\%)$ & o) & $P$ & $\mathrm{~F}$ & o) & & & & $P$ & o) & $\begin{array}{l}E \\
(\%)\end{array}$ & $\mathrm{P}(\%)$ & $\begin{array}{l}F \\
(\%)\end{array}$ & $\begin{array}{l}\mathrm{E} \\
(\%)\end{array}$ & $\mathrm{P}(\%)$ & $\mathrm{F}(\%)$ & E $(\%$ \\
\hline $\mathrm{VC}$ & 59,3 & 75,4 & 43,3 & 60,1 & 70,3 & 41,9 & 64,9 & 82,3 & 46,3 & 64,2 & 75,7 & 45,0 & 62,4 & 71,5 & 48,0 & 64,2 & 66,7 & 50,1 \\
\hline $\mathrm{C}$ & 11,3 & 8,7 & 9,7 & 10,9 & 9,2 & 10,8 & 9,7 & 7,3 & 9,7 & 9,4 & 8,6 & 9,3 & 9,4 & 10,7 & 11,4 & 9,2 & 8,2 & 10,8 \\
\hline FAC & 29,4 & 15,9 & 47,0 & 29,0 & 20,5 & 47,3 & 25,5 & 10,4 & 44,0 & 26,4 & 15,8 & 45,7 & 28,2 & 17,7 & 40,6 & 26,6 & 25,2 & 39,2 \\
\hline
\end{tabular}

\% Course Fassting Rate $=100 * \frac{\text { Passed }+ \text { Exempt }}{\text { Passed }+ \text { Fatl }+ \text { Exempt }}$ Equation 2

$\%$ YD101 $=100 * \frac{5412+3979}{5412+643+3979}=\% 94$

\section{Conclusion and Discussion}

The most important advantage provided by the realized system on the basis of units is that it has minimized issues for assignments of instructors for the courses of 5(I). Assessment and evaluation of students' are realized according to final and resit exams which are on the end of the semester, depending upon 5(I) courses executive rules.

Even though distance education alone is sufficient for the courses and sharing the knowledge, the need of creating individual units about some subjects such as preparing contents or evaluation of students' exams confronts. Besides, it is a must to create an office for instructors to prepare the contents. 
With distance education infrastructure, universities having a financial gain and students' satisfaction level about 5(I) courses increasing, are a sign of suitability this education model. Besides, with Distance Education Research and Application Center Directorship which is newly constituted in Adnan Menderes University being completed an important transition process, the opportunity to make preperation for Undergraduate Degree, Associate Degree, Top-up Degree, and Graduate Degree which are thought to be opened upcoming years is provided.

\section{References}

Adiyaman, Z. (2002). Foreign language teaching through distance learning. The Turkish Online Journal of Educational Technology TOJET, 1(11), 92-97.

Al, U., \& Madran, O. R. (2004). Web based distance education systems: Features and standards that should be possessed. Bilgi Dunyasi, 5(2), 259-271.

Altiparmak, M., Kurt, I. D., \& Kapidere, M. (2011). E-learning and open source code management systems in education (pp. 319-327). Malatya: Akademik Bilisim Konferansi Bildirileri.

Cetin, O., Cakiroglu, M., Bayilmis, C., \& Ekiz, H. (2004). The importance of education for technological development and the place of education in internet supported education. The Turkish Online Journal of Educational Technology-TOJET, 3(3), 144-147.

Duzakin, E., \& Yalcinkaya, S. (2008). Web-based distance education system and the predispositions of Cukurova University lecturers. C.U. Sosyal Bilimler Enstitusu Dergisi, 17(1), 225-244.

Ekiz, H., Bayam, Y., \& Unal, H. (2003). Internet assisted distance learning application for logic circuits course. The Turkish Online Journal of Educational Technology-TOJET, 2(4), 92-99.

Odabas, H. (2003). Internet based distance education and information and document management departments. Turk Kutuphaneciligi, 17(1), 22-36.

Ozarslan, Y. (2008). Open source coded learning management systems for distance learning applications (pp. 55-60). Ankara: Internet Konferansı Bildirileri.

Sinecen, M. (2010). Moodle usage and setup in distance education. Akademik Dizayn Dergisi, 1, 14-21.

Sen, B., Atasoy, F., Aydin, \& Nesrin. (2010). Low cost web based distance learning system. Akademik Bilisim 2010. Mugla: Akademik Bilisim Konferans Bildirileri. 